\title{
MEDICINA PUBLICA
}

O Chefe de Policia pretende inaugurar, no dia $1.0^{\circ}$ de Fevereiro proximo, uma escola de policia, para educação technica dos agentes do Corpo de Segurança.

O curso da escola de policia deve abranger as seguintes materias: $a$ ) noções de criminologia, concernentes ás causas geraes da criminalidade, á classificação dos delinquetes e á psycologia dos malfeitores profissionaes; $b$ ) elementos do Codigo Penal Brasileiro e instrucção relativa á organização policial; c) ensino dos methodos de investigação criminal, destinados a determinar a parte que um individưo ou um objecto tomou num facto criminoso; $d$ ) conhecimento do mundo dos malfeitores pelo estudo do modo do trabalho das varias categorias de criminosos e dos seus habitos, costumes, etc.; $e$ ) ensino pratico do que se chama retrato fallado (descripção dos caracteres particulares da physionomia, proprios a cada individuo), e da dactyloscopia, não só como methodo de identificação judiciaria, mas como methodo efficaz na investigação criminal; $f$ ) conhecimento acerca da funç̧ão da photographia nos inqueritos judiciarios.

O ensino da escola de policia constituirá um só curso, sob a regencia de um mesmo professor, e, sendo essencialmente pratico e experimental. funccionará com um laboratorio de estudos e um museu criminal, onde. se encontre material necessario para as demonstrações.

Li em um dos jornaes que se publicam no Rio de Janeiro a noticia acima, que, relacionando-se em certos pontos com a disciplina que doutrino, prendeume a attenção.

As noções de criminologia concernentes ás causas geraes dá criminalidade, á classificaçẫo dos delinquentes é á psycotogia dos malfeitores profissio- 
naes ; os elementos do Codigo Penal Brasileiro e instrucção relativa á organisação policial, o ensino dos methodos de investigação criminal, destinados a determinar a parte que um individuo ou um objecto tomou no facto criminoso constituem o programma do curso a que tem de se sujeitar os agentes do Corpo de Segurança no Rio de Janeiro, para șua educação technica

Em um só curso e sob a regencia de um mesmo professor, esse programma cujas theses importam questões delicadas e complexas, attinentes á criminologia e á psychologia do individuo. , questões essas, em summa, que abrangem os agentes activo e passivo do facto criminoso, e para cujo conhecimento, mesmo sob o titulo de noções, reclamam um preparo adequado, vae ser um trabalho perdido.

Que tem esses agentes, méros instrumentos auxiliares da autoridade, com as causas geraes da criminalidade?

A etiologia do crime, tão varia e tão complicada, exige o conhecimento do individuo sob o duplo ponto de vista - physiologico e pathologico. Sob o influxo da perturbação de certos estados physiologicos, qual o o puerperio, qual a menstruação, bem como sob a influencia de estados morbidos, o crime pode originar-se.

O diagnostico da causa, subordinado a factores intrinsecos e extrinsecos ao individuo, mesmo aos entendidos no assumpto, torna-se ás vezes tão difficil, que o seu estabelecimento reclama tempo e estudo.

$E$ demais, de que servem essas noções ensinadas á semelhantes agentes de segurança publica? Elles, feita a detenção do criminoso, quando muito, instruem á autoridade competente quem, como, quando e onde o facto succedeu; todas as suas circumstancias, cujo conjuncto, ensina o preclaro professor dr. João Mendes, em sua 


\section{$-63-$}

obra*, representa os elementos sensiveis do facto criminoso.

A' ninguem escapa a responsabilidade que péza sobre quem vê-se ha contingencia de reunir todos esses elementos, aprecial-os, analysal-os e depois enfeichal-os em um diagnostico ao qual se prendem a liberdade e a Konra do seu semelhante.

Um individuo, um operario, em meio de suas occupações, levado por motivo frivolo, qual inoffensivo gracejo de um comparsa, investe contra este desferindolhe golpes que podem occasionar-lhe a morte. O agente de segurança, não obstante as noções deficientes e incompletas que recebeu de criminologia, da classificação dos delinquentes, fará incidir o autor do delicto na classe dos responsaveis pelo facto que commetteu.

Essas noções ensinadas não lhes permittem saber que a epilepsia, sob a sua forma frusta, até então larvada, foi a causa efficiente do mal praticado, effeito de natureza morbida e que isenta-o de responsabilidade, pois é elle um enfermo cuja mente eclypsou-se no momento de praticar o delicto.

Eis ahi um caso em que o agente de segurança teria de mostrar conhecimentos de noções não só de criminologia como tambem de medicina legal, em, desaccordo com as funcções que disvirtuadamente lhes pertencem.

Ensine-se a esses agentes os preceitos da Constituição patria, para que elles no exercicio de suas funcções mantenham-se na orbita de bons auxiliares da autoridade, cumprindo bem os seus deveres e respeitando o direito dos outros.

Nas relações entre a policia e o juiz, aquella, pelos meios que lhe são pertinentès instrue á este para o julgamento do processo. Nada tem ella que ver com as causas geraes da criminalidade e muito menos com

O Processo Criminal Brasileiro. 


\section{$-64-$}

a psychologia do delinquente, que é da alçada do juiz, só do juiz.

$\mathrm{Na}$ obra supra citada, ás paginas 263 , á proposito da discussão que surgiu no parlamento, attinente á reforma judiciaria (1869 e 1870) e em que tomaram parte Alencar Araripe, José de Alencar, então ministro, e outros entre os quaes o Cons. Duarte Azevedo, este assim se enunciou

O criterio estabelecido pelo deputado Araripe é arbitrario. Na formação da culpa institue-se o debate; o reu é admittido á defeza. Ora, isto não pode ser considerado da esphera policial Adverte Faustin Hélie que o processo criminal tem tres periodos: no primeiro periodo limita-se a autoridade a descobrir o crime e o delinquente, á apprehender os instrumentos do delicto e a colher informações; no segundo periodo trata-se de coligir as provas, de reunil-as e de apreciar o caracter legal do facto. Finalmente no terceiro periodo procede-se á abertura do julgamento .

Eis ahi está a procedencia do reparo que faço ao extravagante programma de uma escola de policia para educação technica dos agentes do corpo de segurança, no Rio de Janeiro, que terão de aprender noções de criminologia, concernentes ás causas da criminalidade, e o que mais admira, a psychologia dos malfeitores.

Não estou declamando. Conscio da vastidão dos assumptos que constituem a disciplina que tenho sobre mim ensinar na Faculdade de Direito de S. Paulo, e onde habilito juizes aos quaes incumbe julgar de accordo com os ensinamentos recebidos, ensinamentos estes que consideram a policia meramente parte instructora dos processos, cujo julgamento se faz illuminado pelo parecer de peritos technicos, tenho como dever reparar que á Agentes da Segurança Publica se vá ensinar o que, mesmo sob o titulo de noções, não lhes compete. 


\section{$-65-$}

Ensine-se a esses agentes qual a conducta que devem ter em determinados casos como, supponhamos, nos de enforcamento, de estrangulamento, de afogamento; principalmente naquelle primeiro. Ensine-se-lhes que encontrado um individuo enforcado, já morto, não toquem no corpo, cujo exame deverá ser feito por peritos na posição em que elle foi encontrado, para o diagnostico da causa juridica da morte. Ensine-se-lhes a pensar uma ferida de accordo com os principios ou preceitos modernos da sciencia: ensine-se-lhes a arte photographica para, por meio de apparelhos especiaes, retratarem um individuo suspeito. Ensine-se-lhes os processos modernos empregados para reanimar um afogado e até a simulação de certos estados morbidos ou não, que algumas vezes poderão ser empregados na pesquisa do crime para a captura do criminoso.

Isto sim, é que compete aos agentes de segurança publica e não essas noções constantes do programma que prendeu minha attenção.

A' que papel ficarão reduzidos o chefe de policia e os delegados quando ante elles comparecer um agente de segurança conduzindo um prezo já classificado como um louco, um delinquente de occasião, um passional, ou ao contrario como um individuo são da mente. Seria a inversão dos papeis nessa comedia em que o sapateiro passou a tocar rabecão.

Muito tinha a dizer á respeito; mas, como escrevo para quem pode supprir as lacunas e melhor apontar as incongruencias do citado programma, ahi ficam estas ligeiras considerações para motivarem a palavra dos mais competentes.

S. Paulo, 22 de Janeiro de 1912.

Dr. Amancio de Carvalho. 